\title{
Cloning of the Human Eosinophil Chemoattractant, Eotaxin \\ Expression, Receptor Binding, and Functional Properties Suggest a Mechanism for the Selective Recruitment of Eosinophils
}

\author{
Paul D. Ponath, ${ }^{*}$ Shixin Qin, ${ }^{*}$ Douglas J. Ringler, ${ }^{*}$ lan Clark-Lewis, ${ }^{\ddagger}$ Juan Wang, ${ }^{*}$ Nasim Kassam, ${ }^{*}$ Heidi Smith, ${ }^{*}$ Xiaojie Shi, ${ }^{\star}$ \\ Jose-Angel Gonzalo, ${ }^{\S}$ Walter Newman, ${ }^{*}$ Jose-Carlos Gutierrez-Ramos, ${ }^{\S}$ and Charles R. Mackay ${ }^{\star}$ \\ *LeukoSite, Inc., Cambridge, Massachusetts 02142; ${ }^{\ddagger}$ Biomedical Research Center and Biochemistry and Molecular Biology Department, \\ University of British Columbia, Vancouver, British Columbia, Canada; and ${ }^{\S}$ Center for Blood Research, Harvard Medical School, \\ Boston, Massachusetts
}

\begin{abstract}
The CC chemokine eotaxin, identified in guinea pigs and also recently in mice, may be a key element for the selective recruitment of eosinophils to certain inflamed tissues. Using a partial mouse eotaxin cDNA probe, the human eotaxin gene was cloned and found to be 61.8 and $63.2 \%$ identical at the amino acid level to guinea pig and mouse eotaxin. Human eotaxin protein was a strong and specific eosinophil chemoattractant in vitro and was an effective eosinophil chemoattractant when injected into the skin of a rhesus monkey. Radiolabeled eotaxin was used to identify a high affinity receptor on eosinophils $\left(0.52 \mathrm{nM} K_{\mathrm{d}}\right)$, expressed at $4.8 \times 10^{4}$ sites per cell. This receptor also bound RANTES and monocyte chemotactic protein-3 with lower affinity, but not macrophage inflammatory protein-1 $\alpha$. Eotaxin could desensitize calcium responses of eosinophils to RANTES and monocyte chemotactic protein-3, although RANTES was able to only partially desensitize eosinophil calcium responses to eotaxin. Immunohistochemistry on human nasal polyp with antieotaxin mAbs showed that certain leukocytes as well as respiratory epithelium were intensely immunoreactive, and eosinophil infiltration occurred at sites of eotaxin upregulation. Thus eotaxin in humans is a potent and selective eosinophil chemoattractant that is expressed by a variety cell types in certain inflammatory conditions. (J. Clin. Invest. 1996. 97:604-612.) Key words: chemokines - cytokines - inflammation - eosinophils • chemotaxis
\end{abstract}

\section{Introduction}

Chemoattractant cytokines (chemokines) play an important role in the recruitment of leukocytes to inflammatory lesions (1-4). Over 20 different chemokines have been identified to date, and different chemokines show characteristic biologic activity for distinct subsets of leukocytes. IL-8 is predominantly a

Address correspondence to Charles R. Mackay, LeukoSite, Inc., 215 First Street Cambridge, MA 02142. Phone: 617-621-9350; FAX: 617621-9349; E-mail: 71444.1022@compuserve.com

Received for publication 19 September 1995 and accepted in revised form 24 October 1995.

J. Clin. Invest.

(C) The American Society for Clinical Investigation, Inc.

0021-9738/96/02/0604/09 \$2.00

Volume 97, Number 3, February 1996, 604-612 neutrophil chemoattractant $(2,5)$, while monocyte chemotactic protein $(\mathrm{MCP})^{1}-1$ serves predominantly as a monocyte and $\mathrm{T}$ cell chemoattractant $(6,7)$. Chemokines are produced by a variety of cell types, particularly in inflamed tissue, and endothelial-bound chemokines may provide a migration cue to circulating leukocytes, by signaling through seven transmembrane-spanning G-protein-coupled receptors on the leukocyte $(8,9)$. The notion that chemokines and their receptors play a fundamental role in the recruitment of leukocytes to inflamed tissues is supported by animal models in which anti-IL-8 mAbs inhibit neutrophil recruitment (10-12) and in IL-8 receptor knockout mice in which neutrophil recruitment to inflammatory sites is impaired (13).

Eosinophilic leukocytes also selectively accumulate in some inflammatory tissues, particularly in response to parasitic infection, and also as a result of IgE-mediated reactions such as rhinitis and allergic asthma (14-16). A number of factors have been described as being chemotactic for human eosinophils, including PAF (17), C5a (18), IL-16 (19), and the chemokines RANTES and MCP-3 (20-23), although all of these factors are chemotactic for other cell types. The striking accumulation of eosinophils in certain tissues suggest that there may be factors that are chemotactic specifically for eosinophils. A CC chemokine termed eotaxin was identified as the predominant eosinophil chemoattractant in the bronchoalveolar lavage fluid of allergen challenged guinea pigs (24). Eotaxin was highly potent in guinea pigs, inducing substantial eosinophil accumulation at a 1-2 pmol dose in the skin. Northern blot analysis demonstrated eotaxin mRNA in the lungs of naive and sensitized guinea pigs, although allergen challenge led to considerably increased levels $(25,26)$.

To examine the biology of human eotaxin and its role in disease, we cloned a human homologue of guinea pig eotaxin. Human eotaxin mediated the selective migration of eosinophils, both in vitro and in vivo. Ligand binding and calcium desensitization studies indicated that eotaxin shares a novel receptor with RANTES and MCP-3 on eosinophils, distinct from the CC chemokine receptors CKR-1 (the macrophage inflammatory protein (MIP)-1 $\alpha /$ RANTES receptor) $(27,28)$ and CKR-2a,b (the MCP-1 receptors)(29). Based on the high affinity of eotaxin for its receptor and its selective activity, eotaxin appears to be an important chemokine for human eosinophil function.

1. Abbreviations used in this paper: $\left[\mathrm{Ca}^{2+}\right] \mathrm{i}$, intracellular cytosolic free calcium; MCP, monocyte chemotactic protein; MIP, macrophage inflammatory protein. 


\section{Methods}

Library screening, cDNA isolation, Northern hybridizations. A mouse clone, designated clone 28 , containing a partial mouse eotaxin cDNA encoding murine eotaxin amino acids 17-61 was digested with EcoRI to release a 135-bp fragment (29a). This fragment was labeled by random priming using a kit from Boehringer Mannheim Biochemicals (Indianapolis, IN) following the manufacturer's recommended labeling protocol. This probe was used to screen a human genomic library purchased from Clontech (Palo Alto, CA) using standard molecular biology techniques (30). Hybridization with the mouse clone 28 probe was in $6 \times$ SSC containing $2 \times$ Denhardt's solution and $25 \mu \mathrm{g} / \mathrm{ml}$ denatured salmon sperm DNA overnight at $65^{\circ} \mathrm{C}$. The membranes were rinsed twice in $2 \times \mathrm{SSC}, 0.05 \% \mathrm{SDS}$ at $65^{\circ} \mathrm{C}$ followed by two washes (15 min each) in $0.2 \times \mathrm{SSC}, 0.1 \% \mathrm{SDS}$ at $55^{\circ} \mathrm{C}$. One phage clone, designated clone 25 , was found to contain a nucleotide sequence with significant similarity to the mouse and guinea pig eotaxin clones and was the subject of further analysis.

Human spleen mRNA was purchased from Clontech. The following primers, derived from genomic sequence analysis were used to amplify clone 25 cDNA from human spleen mRNA, 5' primer: 5'-GGATCCAACATGAAGGTCTCCG, 3' primer: 5'-GAATTCTTATGGCTTTGGAG-TTGGAG. $200 \mathrm{ng}$ of spleen mRNA was reverse transcribed with oligo dT. $2 \mu \mathrm{l}$ of this cDNA was amplified with $100 \mathrm{pmol}$ of each primer in a final reaction mixture containing $60 \mathrm{mM}$ Tris- $\mathrm{HCl}, \mathrm{pH} 8.5,2.0 \mathrm{mM} \mathrm{MgCl} 2,200 \mathrm{mM}$ dNTPs, and $2.5 \mathrm{U}$ Taq polymerase. The cycle parameters for PCR were as follows: $95^{\circ} \mathrm{C}, 1$ min; 25 cycles of $94^{\circ} \mathrm{C}, 30 \mathrm{~s} ; 68^{\circ} \mathrm{C}, 10 \mathrm{~s} ; 72^{\circ} \mathrm{C}, 10 \mathrm{~s} ; 72^{\circ} \mathrm{C}, 6 \mathrm{~min}$. The PCR fragment was digested with EcoRI and BamHI and cloned into appropriate vectors for further analysis.

Multiple tissue Northern blots were purchased from Clontech and probed with the full-length human clone $25 \mathrm{cDNA}$ labeled as described above for the mouse clone 28 probe. The blots were prehybridized for $2 \mathrm{~h}$ at $68^{\circ} \mathrm{C}$ in ExpressHyb ${ }^{\mathrm{Tm}}$ solution (Clontech) followed by hybridization for $1 \mathrm{~h}$ at the same temperature. The blots were washed twice for $20 \mathrm{~min}$ in $2 \times \mathrm{SSC}, 0.05 \% \mathrm{SDS}$ at $65^{\circ} \mathrm{C}$ followed by two washes for $20 \mathrm{~min}$ in $0.2 \times \mathrm{SSC}, 0.1 \% \mathrm{SDS}$ at $65^{\circ} \mathrm{C}$. Under these conditions, the full-length human clone 25 probe hybridizes with a single fragment on genomic Southern blots (data not shown).

Preparation of human eosinophils, neutrophils, and PBMC. Human neutrophils were isolated from heparinized venous blood by Percoll density gradient centrifugation $(\delta=1.088)$ at room temperature (31). RBCs were removed by hypotonic lysis. Eosinophils were isolated from the blood of individuals with high levels of circulating blood eosinophils (5-17\%) by combined density gradient centrifugation and negative selection with anti-CD16 magnetic beads (32). Briefly, the granulocyte fraction from the Percoll centrifugation was incubated with CD16 microbeads (Miltenyi Biotec Inc., Sunnyvale, CA) for $30 \mathrm{~min}$. Cells were then passed through a MACS column (Miltenyi Biotec Inc.), and eosinophils were collected in the flow through. Eosinophil purity was $>99 \%$ as determined by analysis of Diff-Quik-stained cytocentrifugation preparations by light microscopy. PBMCs were obtained as described (31).

Chemokines and chemotaxis. Recombinant human chemokines were obtained from Peprotech Inc. (Rocky Hill, NJ). Human eotaxin was synthesized using solid-phase methods that were optimized and adapted to a fully automated peptide synthesizer (430A; Applied Biosystems, Inc., Foster City, CA) as described elsewhere (33). Leukocyte chemotaxis was assessed using a modification of a transendothelial assay (6). The endothelial cells used for this assay were the endothelial cell line ECV 304 (34), obtained from the European Collection of Animal Cell Cultures (Porton Downs, UK). Endothelial cells were cultured on 6.5 -mm diameter Transwell culture inserts (Costar Corp., Cambridge, MA) with a 3.0- $\mu \mathrm{m}$ pore size. Culture media for ECV 304 cells consisted of M199 + 10\% FCS, L-glutamine, and antibiotics. Assay media consisted of equal parts RPMI 1640 and M199, with $0.5 \%$ BSA. 24 h before the assay, $2 \times 10^{5}$ ECV 304 cells were plated onto each insert of the 24 -well chemotaxis plate, and in- cubated at $37^{\circ} \mathrm{C}$. Chemotactic factors (diluted in assay medium) were added to the 24-well tissue culture plates in a final vol of $600 \mu$ l. Endothelial-coated Transwells were inserted into each well and $10^{6}$ leukocytes were added to the top chamber in a final vol of $100 \mu \mathrm{l}$. The plate was then incubated at $37^{\circ} \mathrm{C}$ in $5 \% \mathrm{CO}_{2} / 95 \%$ air for $1-4 \mathrm{~h}$, depending on the leukocyte type being studied. The cells that had migrated to the bottom chamber were counted using flow cytometry. $500 \mu \mathrm{l}$ of the cell suspension from the lower chamber was placed in a tube, and relative cell counts were obtained by acquiring events for a set time period of $30 \mathrm{~s}$. This counting method was found to be highly reproducible, and enabled gating on the leukocytes and the exclusion of debris or other cells. Counts obtained in this way matched closely those obtained by counting with a microscope.

Measurement of intracellular cytosolic free calcium $\left[\mathrm{Ca}^{2+}\right]$ i. Eosinophils were labeled with the fluorochrome Fluo-3 (Molecular Probes, Eugene, OR) according to the manufacturer's recommendations. Briefly, $50 \mu \mathrm{g}$ of Fluo-3 was dissolved in $44 \mu \mathrm{l}$ of DMSO and diluted to $10 \mu \mathrm{M}$ with modified Gay's buffer (MGB; $5 \mathrm{mM} \mathrm{KCl}, 147 \mathrm{mM}$ $\mathrm{NaCl}, 0.22 \mathrm{mM} \mathrm{KH} \mathrm{PO}_{4}, 1.1 \mathrm{mM} \mathrm{Na} \mathrm{HPO}_{4}, 5.5 \mathrm{mM}$ glucose, $0.3 \mathrm{mM}$ $\mathrm{MgSO}_{4} \cdot 7 \mathrm{H}_{2} \mathrm{O}, 1 \mathrm{mM} \mathrm{MgCl}$, and $10 \mathrm{mM}$ Hepes, $\mathrm{pH}$ 7.4). Cells were resuspended in MGB to $10^{7}$ cells $/ \mathrm{ml}$, and incubated with an equal vol of $10 \mathrm{mM}$ Fluo-3 mix for $30 \mathrm{~min}$ at room temperature. Cells were then washed twice with MGB and resuspended at $2 \times 10^{6} \mathrm{cells} / \mathrm{ml}$ in MGB. The $\left[\mathrm{Ca}^{2+}\right]$ i was measured on the FACScan ${ }^{\circledR}$, by analyzing FL1 (linear scale) versus time.

$m A b s$. mAbs were produced against human eotaxin by immunizing mice with $10 \mu \mathrm{g}$ of synthesized Eotaxin, three times over a period of $4 \mathrm{wk}$. The first immunization was intraperitoneal with Freund's complete adjuvant, the second was intraperitoneal with Freund's incomplete adjuvant, and the final immunization was protein alone intravenous. $4 \mathrm{~d}$ after the last immunization, the spleen was taken, and cell fusion was performed using the cell line SP2/O, as described (31).

ELISA. ELISA was performed by coating $50 \mu \mathrm{l}$ of eotaxin or recombinant MCP-1, MCP-3, or other chemokines onto 96-well Maxisorp plates (Nunc Inc., Naperville, IL), at a concentration of $2 \mu \mathrm{g} / \mathrm{ml}$ in carbonate buffer, for at least $4 \mathrm{~h}$ at $4^{\circ} \mathrm{C} .300 \mu \mathrm{l} /$ well of blocking buffer (PBS $+1 \%$ BSA) was added for at least $2 \mathrm{~h}$, or until the day of the assay. Plates were washed $4 \times$ with PBS/Tween 20 , and $50 \mu l$ of mAb supernatant was added to each well and incubated at $37^{\circ} \mathrm{C}$ for $1 \mathrm{~h}$. Plates were washed $4 \times$ with PBS/Tween 20 and alkaline phosphatase-conjugated second antibody (Jackson ImmunoResearch Laboratories, Inc., West Grove, PA) diluted 1:500 in PBS was added to each well. After an incubation at $37^{\circ} \mathrm{C}$ for $30 \mathrm{~min}$, plates were washed $4 \times$ with PBS/Tween 20 . The substrate used for the color reaction was $p$-nitrophenylphosphate dissolved in diethanolamine buffer (Bio-Rad Laboratories, Richmond, CA). Plates were read at $410 \mathrm{~nm}$ on an ELISA reader.

Immunohistochemistry. Immunohistochemical analysis for human eotaxin protein was performed on formalin-fixed, paraffinembedded samples of nasal polyps using techniques previously described $(35,36)$. Briefly, deparaffinized sections were postfixed in $0.6 \% \mathrm{H}_{2} \mathrm{O}_{2}$ in methanol for $20 \mathrm{~min}$ at room temperature to remove endogenous peroxidase activity, followed by blocking with PBS $/ 10 \%$ goat serum for $30 \mathrm{~min}$ at room temperature. Anti-human eotaxin $\mathrm{mAb}$ (or irrelevant $\mathrm{mAb}$ ) was then used as neat tissue culture supernatant overnight at $4^{\circ} \mathrm{C}$, followed by biotinylated goat anti-mouse IgG (Vector Laboratories, Burlingame, CA), and avidin-biotin-peroxidase complexes (Vector Laboratories). Diaminobenzidine was used as the chromagen and Mayer's hematoxylin as the counterstain. Sections immunostained for eotaxin were compared to step sections with hematoxylin and eosin to evaluate spatial associations with eosinophil infiltration.

Ligand binding assay. ${ }^{125} \mathrm{I}$-labeled RANTES were purchased from DuPont NEN (Boston, MA), with a sp act of 2,200 Ci/mM. ${ }^{125}$ I-labeled eotaxin was produced using the Bolton Hunter reagent (DuPont NEN), as described (31). The specific activity of radiolabeled eotaxin was calculated to be $180 \mathrm{Ci} / \mathrm{mM}$. Chemokine binding to target cells was carried out using a modified method previously re- 
A

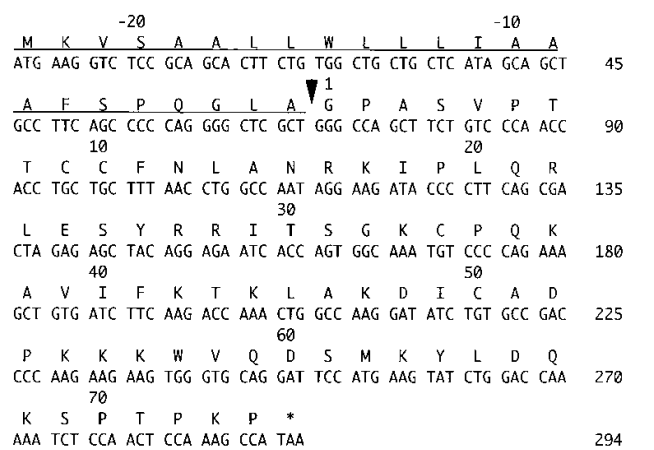

B

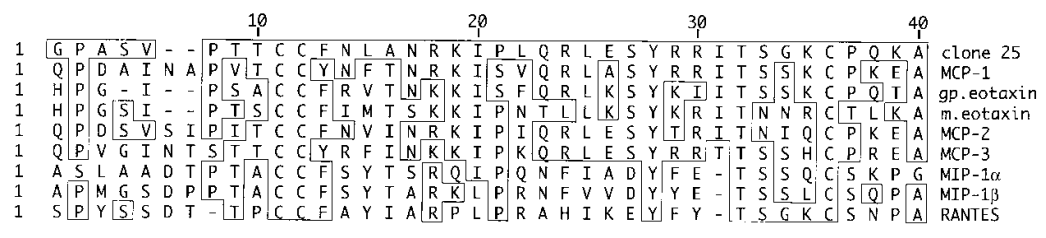

50

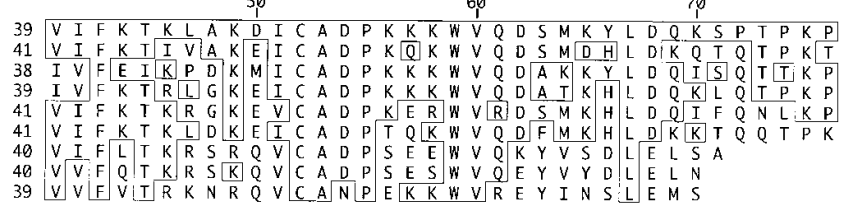

clone 25

MCP-1

gp. eotaxin

m. eataxin
$M C P-2$

$M C P-3$

MCP-3
MIP-1 $1 \alpha$

MIP-1 $\alpha$

RANTES

Figure 1. (A) Nucleotide sequence and deduced amino acid sequence of human clone 25 cDNA coding region. The underlined amino acids correspond to the predicted signal sequence with the arrowhead indicating the predicted signal peptidase cleavage site. $(B)$ Amino acid sequence alignment of the predicted mature clone 25 protein with other human CC chemokines as well as guinea pig and mouse eotaxin. Amino acid numbering is relative to clone 25 , and amino acids identical to clone 25 are boxed. These sequence data are available from GenBank under accession number U34780.

ported (37). Cells were washed once in PBS and resuspended in binding buffer (50 mM Hepes, $1 \mathrm{mM} \mathrm{CaCl}_{2}, 5 \mathrm{mM} \mathrm{MgCl}_{2}$, and $0.5 \% \mathrm{BSA}$ ) at a concentration of $1 \times 10^{7} / \mathrm{ml}$. Aliquots of $50 \mu \mathrm{l}\left(5 \times 10^{5}\right.$ cells $)$ were dispensed into microfuge tubes, followed by the addition of cold competitor and radiolabeled chemokines as indicated in the text. The final reaction vol was $200 \mu$ l. Nonspecific binding was determined by incubating cells with radiolabeled chemokines in the presence of $250-$ $500 \mathrm{nM}$ of cold chemokines. After 60-min incubation at room temperature, the cells were washed three times, with $1 \mathrm{ml}$ of binding buffer plus $0.5 \mathrm{M} \mathrm{NaCl}$. Cell pellets were then counted. All experiments were carried out using duplicates and repeated at least three times. Curve fit was calculated by KaleidaGraph software (Synergy Software, Reading, PA).

In vivo assessment of eosinophil recruitment. A male adult rhesus monkey was injected intradermally at nine sites on the back with 10 , 100 , or 1,000 pmol of either eotaxin, RANTES, or BSA in $0.1 \mathrm{ml}$ PBS. Full thickness skin biopsies $(6 \mathrm{~mm})$ were taken from these sites at $4 \mathrm{~h}$ after injection. These tissues were fixed in formalin, embedded in paraffin, and sectioned for histological analysis by staining with hematoxylin and eosin. Quantitative, computer-assisted morphometric analysis of skin sections was performed using a Quantimet 500 Image Analyzer (Leica Inc., Deerfield, IL). The relative density (number cells $/ \mathrm{mm}^{2}$ ) of eosinophils was enumerated on at least five random fields per section just adjacent to and including the postcapillary venules of the superficial vascular plexus. Cells were selected based on the color wavelength generated from eosin-stained cytoplasmic granules of eosinophils, and color selection criteria were identical on all sections analyzed. The number of eosinophils $/ \mathrm{mm}^{2}$ of dermis was then calculated.

\section{Results}

Cloning of a human eotaxin. A candidate human homologue of guinea pig eotaxin was cloned using the following approach. First, using degenerate primers deduced from the guinea pig sequence (25), a partial cDNA for a candidate mouse eotaxin was cloned (29a). Screening of a human genomic library with a mouse probe yielded 11 phage which were plaque purified and analyzed by restriction digest. One phage, designated clone 25 , contained a 1.0-kb HindIII and a 5.5-kb Pst fragment which hybridized with the murine eotaxin probe. These fragments were subcloned, sequenced, and found to contain a nucleotide sequence with significant similarity to other chemokine genes. To determine if this genomic clone encoded a functional gene, specific primers were used to amplify a cDNA. Fig. $1 A$ shows the nucleotide sequence and predicted amino acid sequence of the amplified product from human spleen mRNA. Clone 25 encodes a 97 amino acid protein including a putative hydrophobic leader peptide of 23 amino acids with a leader peptidase cleavage site predicted by amino acid consensus and comparison with other chemokine sequences. This protein is a member of the $\mathrm{CC}$ chemokine family as indicated by the cysteine pair at amino acid position 9 and 10 in Fig. $1 A$.

Fig. $1 B$ shows an amino acid sequence alignment of the predicted mature clone 25 protein with other members of the $\mathrm{CC}$ chemokine family. This protein shows highest amino acid sequence identity to human MCP-1 and human MCP-2, both at $64.5 \%$ followed by mouse eotaxin, guinea pig eotaxin, and human MCP-3 with 63.2, 61.8, and 57.7\%, respectively. Lower amino acid sequence identity is observed with human MIP-1 $\beta$ (36.8\%), human RANTES (34.2\%), and human MIP- $1 \alpha$ (32.9\%). Interestingly, further comparison shows that clone 25 shares with both guinea pig and mouse eotaxin a two amino acid deletion between positions 5 and 6 (Fig. $1 B$ ) suggesting that clone 25 is the human homologue of the murine and guinea pig eotaxin genes. Comparison of the putative $\mathrm{NH}_{2}$ terminus of clone 25 shows, however, that it does not share either the glutamine residue essential for optimal MCP-1 function (38) or the basic histidine residue present in both the mouse and guinea pig eotaxin sequence. A comparison between clone 25 and the guinea pig and mouse eotaxins also shows that the $\mathrm{NH}_{2}$ terminus is poorly conserved, with only the two prolines at amino acid positions 2 and 6 completely conserved. Amino acids 51-62 are absolutely conserved, and based on the nuclear magnetic resonance structure of RANTES, this region is hypothesized to form a loop connecting a $\beta$-sheet of the chemokine core with the COOH-terminal $\alpha$-helix (39).

Screening of multiple tissue Northern blots containing $2 \mu \mathrm{g}$ of poly A + selected RNA revealed a major hybridizing message at $\sim 0.8 \mathrm{~kb}$ with the highest level of expression in the small intestine and colon (Fig. 2). There was also a detectable level of expression in heart. No detectable level of mRNA ex- 

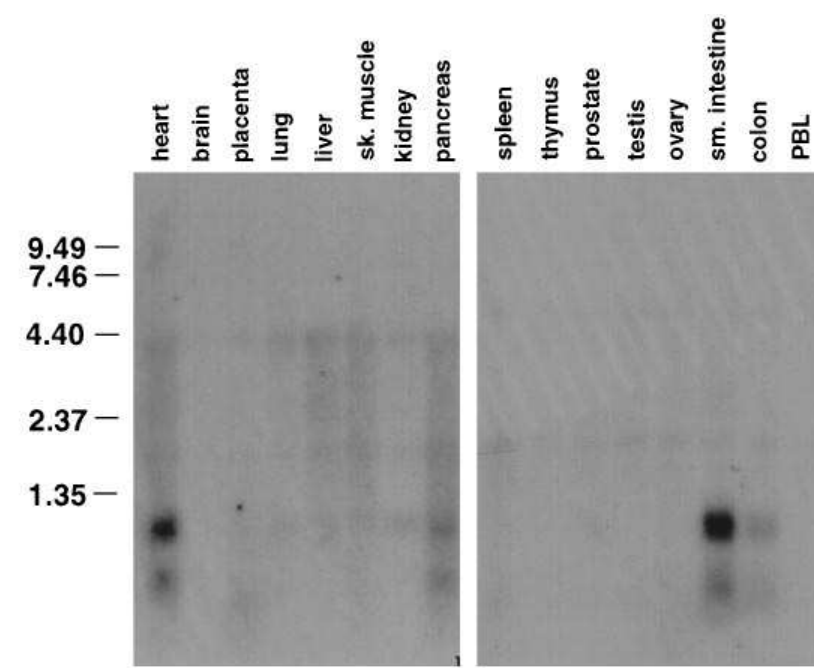

\section{$\beta$-actin -}
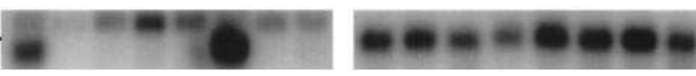

Figure 2. Northern analysis of $\sim 2 \mu \mathrm{g}$ of oligo-dT-selected RNA from various human tissues. Blots were purchased from Clontech and hybridized as described in Methods. After boiling in $0.5 \%$ SDS to remove specific probe, the blots were rehybridized with a $\beta$-actin control.

pression was evident in other tissues under the conditions described, however clone $25 \mathrm{cDNA}$ has been amplified by PCR from spleen, thymus, and purified eosinophils (not shown).

In vitro chemotactic response of human leukocytes to a putative human eotaxin. The protein encoding clone 25 (deduced from the nucleotide sequence) was chemically synthesized and folded, following procedures used previously for other CC chemokines (38). Human eosinophils, neutrophils, monocytes, and lymphocytes were assessed for their response to different concentrations of this as well as other chemokines in a sensitive transendothelial chemotaxis assay (Fig. 3). The chemokine encoded by clone 25 was a strong chemoattractant for eosinophils, and usually showed a similar activity to RANTES and MCP-3, two well characterized eosinophil chemoattractants (20-23). We observed only modest chemotaxis of human eosinophils to MIP- $1 \alpha$ or IL-8 in normal donors, although eosinophils from an individual with a history of asthma and very high eosinophil levels responded to these chemokines. The chemokine encoded by clone 25 was not chemotactic for human neutrophils or lymphocytes (Fig. 3) and mediated only a weak response in monocytes at very high doses $(>1,000 \mathrm{ng} / \mathrm{ml})$. Anti-CD3-activated T cells were unresponsive at all concentrations tested (not shown). The use of endothelial cells in the chemotaxis assay enables a significant improvement in signal to noise $(6,40)$, sometimes reaching values of 200:1. In bare filter chemotaxis assays, the typical bell shaped curve was obtained, and the concentration of eotaxin that yielded the greatest eosinophil migration was $100 \mathrm{ng} / \mathrm{ml}$. A checkerboard analysis with various concentrations of clone 25 protein showed that the migration of eosinophils was chemotactic rather than chemokinetic.

In vivo recruitment of rhesus monkey eosinophils to a putative human eotaxin. To test the in vivo role of the chemokine encoded by clone 25 , an adult rhesus monkey was injected intradermally with 10,100 , or 1,000 pmol of either clone 25 pro-
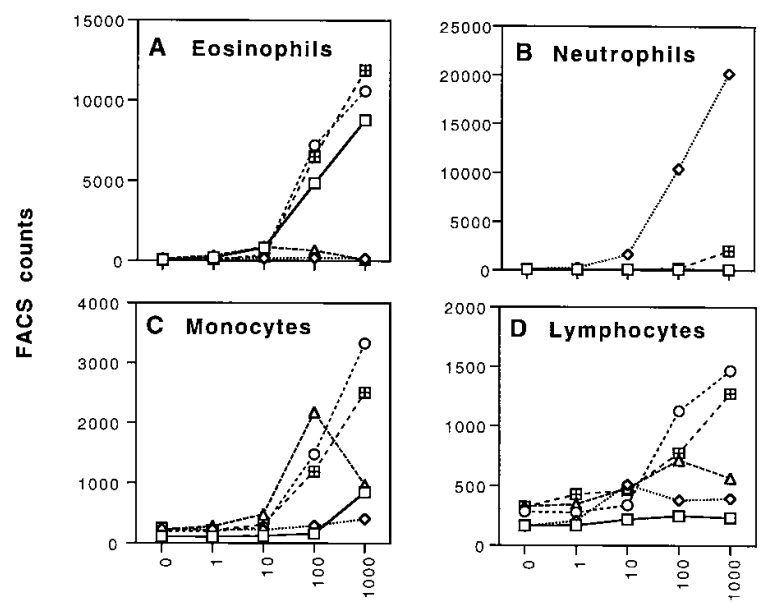

ng Chemokine

Figure 3. Chemotactic responses of human leukocytes to eotaxin and other chemokines. Human eosinophils $(A)$, neutrophils $(B)$, monocytes $(C)$, and lymphocytes $(D)$ were assessed in transendothelial chemotaxis assays to $1,10,100$, and $1,000 \mathrm{ng} / \mathrm{ml}$ of various chemokines. Cells migrating from the top well of the Transwell to the bottom well were enumerated by counting for $30 \mathrm{~s}$ with a FACScan ${ }^{\circledR}$.

The endothelial cells used for coating the polycarbonate membrane of the Transwell were ECV304 cells. Values are a representative experiment of at least six performed. $\square$, eotaxin; $\diamond$, IL-8; $\bigcirc$, RANTES; $\triangle$, MIP- $1 \alpha ; \boxplus$, MCP-3.

tein, human RANTES, or BSA. Histologic assessment and quantitative image analysis of skin biopsies showed no recruitment of eosinophils with BSA at doses of 10 and $100 \mathrm{pmol}$, and only a rare isolated eosinophil at 1,000 pmol (Fig. 4). The greatest eosinophil recruitment was observed at the injection site for 1,000 pmol of clone 25 protein, or human RANTES, which was characterized histologically by foci consisting of 5-10 eosinophils adjacent to postcapillary venules of the superficial vascular plexus in the dermis, as well as clusters of eosinophils scattered throughout the dermal collagen bundles. The chemokine encoded by clone 25 elicited recruitment of eosinophils at 10,100, and 1,000 pmol, whereas RANTES elicited a response only at $1,000 \mathrm{pmol}$. Although nonspecific dermal recruitment of occasional neutrophils was apparent in all specimens, including those injected with BSA, the leukocyte

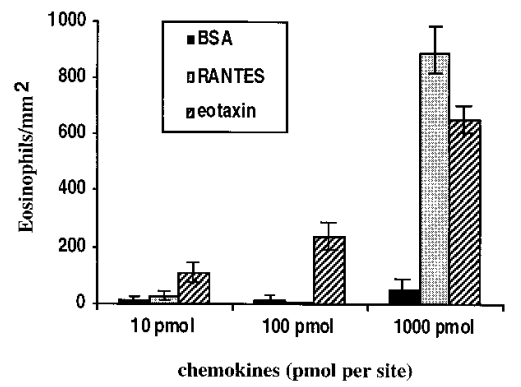

Figure 4. Recruitment of eosinophils to the skin of a rhesus monkey injected with clone 25 protein, RANTES, or BSA. An adult rhesus monkey was injected intradermally with 10,100 , or 1,000 pmol of either clone 25 protein, RANTES, or BSA. Full thickness

skin biopsies $(6 \mathrm{~mm})$ were taken from these sites at $4 \mathrm{~h}$ after injection, and histologic assessment and quantitative image analysis of skin biopsies was performed. The relative density (number cells $/ \mathrm{mm}^{2}$ ) of eosinophils was enumerated on at least 5 random fields/section just adjacent to and including the postcapillary venules of the superficial vascular plexus. 
types recruited to the clone 25-challenged site were $>90 \%$ eosinophils. In contrast, although eosinophils were recruited to the 1,000 pmol RANTES injection site, increased numbers of perivascular mononuclear cells were observed in all RANTES injection sites, similar to the infiltrate observed in a previous study with dogs (41).

Because of the high sequence similarity between clone 25 and guinea pig eotaxin, and the fact that this chemokine is selectively chemotactic for eosinophils in vitro and in vivo, this chemokine will henceforth be referred to as human eotaxin.

Human eotaxin desensitizes $\left[\mathrm{Ca}^{2+}\right]$ i responses of eosinophils to most $C C$ chemokines. The transient elevation in $\left[\mathrm{Ca}^{2+}\right] \mathrm{i}$ in cells upon chemokine binding can be used to monitor receptor activation, and the desensitization that occurs through a given receptor can provide some insight into receptor usage by different agonists $(20,42,43)$. Fluo-3-loaded eosinophils $(>99 \%$ purity) showed a strong, rapid, and transient rise in $\left[\mathrm{Ca}^{2+}\right] \mathrm{i}$ after stimulation with $50 \mathrm{nM}$ of human eotaxin (Fig. 5). A similar
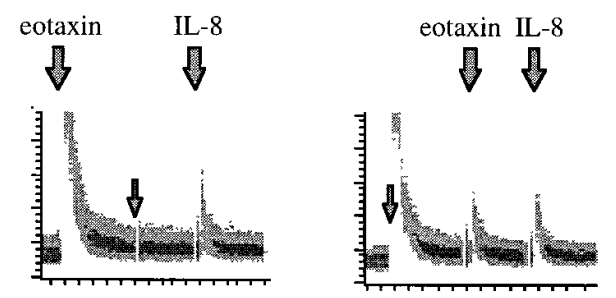

RANTES
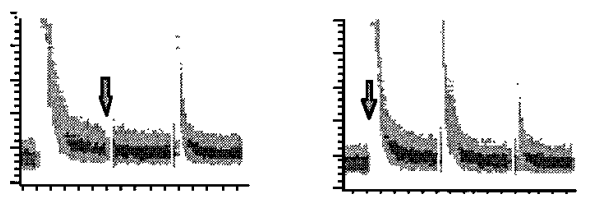

MCP-3
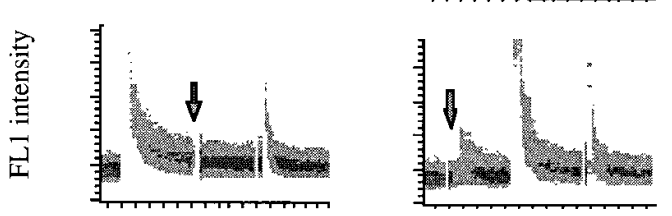

MIP-1 $\alpha$
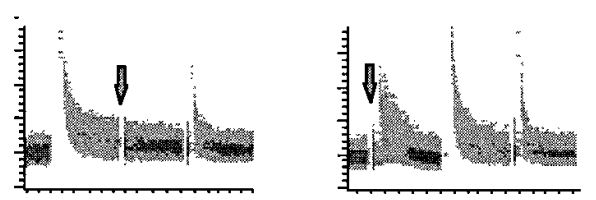

MCP-1
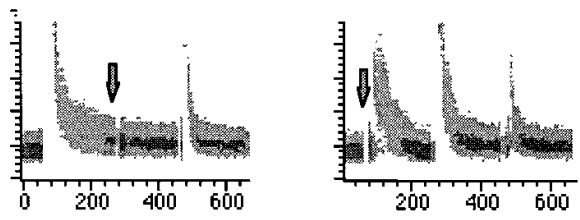

MCP-2

Time (sec.)

Figure 5. Changes in the cytosolic free calcium concentration in human eosinophils in response to various chemokines. In the first set of experiments (left hand plots), eotaxin was added first, followed by a test chemokine indicated on the right of the figure, followed by IL-8. In the second set of experiments (right hand plots), test chemokine were added first, followed by eotaxin, followed by IL-8. Chemokines were added at the points indicated by arrows to a final concentration of $50 \mathrm{nM}$. In this experiment, IL-8 induced a calcium flux on a proportion of eosinophils and was used for control purposes at $50 \mathrm{nM}$. FL1, linear scale. response was observed with $50 \mathrm{nM}$ human RANTES, and 50 nM MCP-3. An advantage of using the FACScan ${ }^{\circledR}$ for $\left[\mathrm{Ca}^{2+}\right] \mathrm{i}$ analysis is that the proportion of cells responding to a given ligand can be assessed. All eosinophils responded to eotaxin, RANTES, and MCP-3, but only a proportion $(\sim 20-30 \%)$ responded to MIP- $1 \alpha$, IL-8, or MCP-1, although these values were variable from donor to donor. $50 \mathrm{nM}$ of human eotaxin was able to completely desensitize eosinophils to subsequent stimulation with $50 \mathrm{nM}$ RANTES, MCP-3, MCP-1, MIP-1 $\alpha$, and MCP-2 (Fig. 5). In addition, 50 or $100 \mathrm{nM}$ RANTES could only partially desensitize eosinophils to subsequent stimulation with $50 \mathrm{nM}$ of human eotaxin. However a range of concentrations of MCP-3, MCP-2, MCP-1, or MIP-1 $\alpha$ (10-100 $\mathrm{nM}$ ) were unable to desensitize subsequent responses to eotaxin. In all of the analyses, IL- 8 was used as a control, since none of the $\mathrm{CC}$ chemokines could desensitize eosinophil responses to IL-8.

Human eotaxin binds with high affinity to a receptor on eosinophils. The expression of the receptor for eotaxin on eosinophils was examined using ligand binding with radiolabeled eotaxin and RANTES. Fig. $6 \mathrm{~A}$ shows the binding of ${ }^{125} \mathrm{I}$ labeled eotaxin to human eosinophils, in the presence of increasing concentrations of "cold" competitors. ${ }^{125}$ I-labeled eotaxin bound to eosinophils, and this binding could be competed efficiently with cold eotaxin. Binding could also be competed with cold MCP-3 and RANTES, although MCP-3 and RANTES competed less efficiently than eotaxin for ${ }^{125} \mathrm{I}$ -

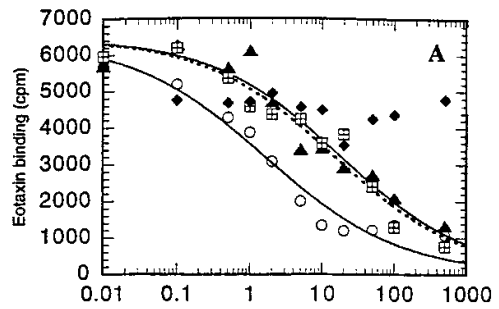

Figure 6. Competitive binding of chemokines to human eosinophils. Purified human eosinophils were resuspended in binding buffer (50 mM Hepes supplemented with $0.5 \%$ BSA, $1 \mathrm{mM} \mathrm{CaCl}_{2}$, and $5 \mathrm{mM} \mathrm{MgCl}_{2}$ ). Into each microfuge tube were

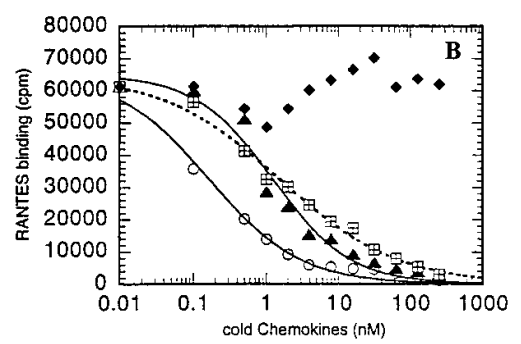
added $5 \times 10^{5}$ eosinophils, various concentrations of unlabeled chemokines, and $1 \mathrm{nM}$ radiolabeled eotaxin

$(A)$, or $0.1 \mathrm{nM}$ radiolabeled RANTES $(B)$. After $60 \mathrm{~min}$ at room temperature, the cell pellets were washed and counted as described in Methods. Points generated by cold MIP-1 $\alpha$ could not be analyzed by the curve fit program as there was no competition at the concentrations used. $C$ shows a Scatchard plot using unlabeled eotaxin to compete with radiolabeled eotaxin binding to human eosinophils. It reveals a $K_{\mathrm{d}}$ of $0.52 \mathrm{nM}$ and $4.8 \times 10^{4}$ binding sites per cell. These data are representative of at least three experiments. $\bigcirc$, eotaxin; $\boldsymbol{\Lambda}$, RANTES; $\boxplus, \mathrm{MCP}-3 ; \diamond$, MIP- $1 \alpha$. 
Table I. Properties of a Panel of Antieotaxin mAbs

\begin{tabular}{|c|c|c|c|c|}
\hline $\mathrm{mAb}$ & Isotype & Specificity* & $\begin{array}{c}\text { Neutralizing } \\
\text { activity }\end{array}$ & $\begin{array}{l}\text { Staining } \\
\text { paraffin } \\
\text { sections }\end{array}$ \\
\hline $6 \mathrm{H} 9$ & IgG1 & eotaxin & - & + \\
\hline $5 \mathrm{E} 9$ & IgG1 & eotaxin & - & + \\
\hline $5 \mathrm{H} 2$ & IgG1 & eotaxin & - & + \\
\hline 6D9 & IgG1 & eotaxin & - & + \\
\hline $9 \mathrm{H} 3$ & $\operatorname{IgG} 2 b$ & eotaxin & + & - \\
\hline $3 \mathrm{C7}$ & IgG1 & eotaxin & + & - \\
\hline 6E6 & IgG1 & $\begin{array}{l}\text { eotaxin, MCP-1, } \\
\text { MCP-3 }\end{array}$ & - & ND \\
\hline
\end{tabular}

* Specificity was determined by ELISA using plates coated with eotaxin, MCP-1, MCP-3, RANTES, or MIP- $1 \alpha .{ }^{\ddagger}$ Neutralizing ability was assessed by $\mathrm{mAb}$ inhibition of ${ }^{125}$ I-labeled eotaxin binding to human eosinophils and by inhibition of chemotaxis. ${ }^{\S} \mathrm{mAb}$ staining of paraffin sections was assessed using human nasal polyp.

labeled eotaxin binding. MIP- $1 \alpha$ was not able to compete with ${ }^{125}$ I-labeled eotaxin binding under the conditions used, suggesting that eotaxin binding to eosinophils was through a receptor other than CKR-1 (the MIP-1 $\alpha /$ RANTES receptor). This was confirmed using CC CKR1-expressing transfectants and cell lines; ${ }^{125}$ I-labeled eotaxin was unable to bind these cells, and cold eotaxin was unable to compete with ${ }^{125}$ I-labeled RANTES binding (not shown). Competitive binding by unlabeled eotaxin produced a Scatchard plot (Fig. $6 \mathrm{C}$ ), which revealed a single binding site for eotaxin on eosinophils, a $K_{\mathrm{d}}$ of $0.52 \mathrm{nM}$, and $4.8 \times 10^{4}$ binding sites per cell. Scatchard plots using ${ }^{125}$ I-labeled RANTES revealed similar binding sites per cell. In a similar set of experiments, eosinophils were incubated with ${ }^{125}$ I-labeled RANTES (Fig. $6 \mathrm{~B}$ ), and increasing concentrations of cold eotaxin, RANTES, MCP-3, or MIP- $1 \alpha$. Binding of ${ }^{125} \mathrm{I}$-labeled RANTES to human eosinophils could be efficiently competed with cold eotaxin, and eotaxin was a much more efficient competitor than cold MCP-3 or RANTES.

Expression of eotaxin in tissues and upregulation at a site of eosinophil recruitment. A panel of $50 \mathrm{mAbs}$ was produced to human eotaxin by immunizing mice with the chemically synthesized material, and screening for specific mAbs by ELISA. The majority of the mAbs were found to be specific for eotaxin, in that they showed strong reactivity with eotaxin, and no reactivity with human MCP-1, MCP-3, RANTES, or MIP$1 \alpha$, as assessed by ELISA. Several of the mAbs recognized an epitope shared between eotaxin, MCP-3, and MCP-1. The properties of seven select mAbs are outlined in Table I. Two of the eotaxin-specific mAbs were noted for their ability to block the binding of ${ }^{125}$ I-labeled eotaxin to human eosinophils, and/or the chemotaxis of eosinophils to eotaxin in transendothelial chemotaxis assays. Four of the mAbs were able to recognize an epitope of human eotaxin that is preserved in paraffin-embedded tissue specimens.

Immunohistochemical analysis was performed with a representative $\mathrm{mAb}, 6 \mathrm{H} 9$, using human nasal mucosa and polyp tissue with pronounced submucosal eosinophil infiltration. Eotaxin staining was localized most strongly to overlying ciliated pseudostratified columnar epithelium (Fig. 7). Various leukocyte types also stained positively, including eosinophils, lymphocytes, and macrophages (Fig. 7). Care was taken to ensure the eosinophil staining was bona fide and not due to endoge- nous peroxidase. No immunoreactivity to any cell type was recognized in the same tissue using an irrelevant IgG1 mAb. There was a strong correlation between eosinophil infiltration within the mucosa and submucosa of the polyp and eotaxin expression to resident cells and leukocytes. Specifically, in areas of eosinophil localization in polyp tissue, there was an increase in the number of antieotaxin immunoreactive macrophages, endothelial cells, fibroblasts, smooth muscle cells, lymphoid cells, epithelial cells, and eosinophils, when compared to uninvolved nasal mucosa. In addition, there was a concomitant increase in staining intensity of immunoreactive cells in the polyp tissue compared to adjacent uninvolved nasal mucosa.

\section{Discussion}

Here we identify a novel human chemokine that is selectively chemotactic for eosinophils. Based on sequence similarity and function, this chemokine can be considered a human equivalent of guinea pig and murine eotaxin. A hallmark of guinea pig eotaxin is its high degree of specificity for eosinophils, which sets it apart from the other eosinophil chemoattractants such as C5a, PAF, RANTES, and MCP-3, which are chemotactic for other leukocyte types. Human eotaxin was highly selective for eosinophils, although at very high doses it was chemotactic for a very small number of monocytes, possibly due to low affinity binding to a monocyte CC chemokine receptor. Human eotaxin was usually as effective as RANTES or MCP-3 as an eosinophil chemoattractant, although we did observe donor to donor variation in the relative response to eotaxin, RANTES, and MCP-3. The nature of an individual's eosinophils, such as activation status or exposure to IL-5, may affect the responses of eosinophils to different chemokines.

Studies with a single rhesus monkey showed that human eotaxin was also effective at recruiting eosinophils to challenged skin sites. A study in guinea pigs showed that eotaxin induced substantial eosinophil accumulation in the skin at a 1-2 pmol (24), which is a much lower dose than what we found to be optimal in our study. The recruitment of eosinophils to tissues may relate not only to the presence of chemokine within the tissue, but also other factors such as the relative numbers of eosinophils within the blood. IL-5 has been found to synergize with eotaxin in the recruitment of guinea pig eosinophils to challenged sites; the IL-5 functioned in the mobilization of eosinophils from the bone marrow to the blood, and the eotaxin acted locally for the recruitment of eosinophils (44). IL-5 is an eosinophil differentiation and activating factor (15) and has been found to affect responsiveness of eosinophils to IL-8 (45). RANTES injections into the skin of a rhesus monkey led to the recruitment of both eosinophils and mononuclear cells to the challenged sites, similar to a previous report using dogs (41) and consistent with the in vitro chemotactic profile of RANTES in humans.

The existence of an eosinophil-specific chemokine may explain the highly selective accumulation of eosinophils in some inflammatory sites. This may have important implications, since excessive recruitment of eosinophils to mucosal tissues may contribute to the pathogenesis of asthma and other human diseases $(16,46)$. Northern blot analysis as well as immunohistochemistry confirmed previous studies in guinea pig that eotaxin in humans is expressed constitutively in some tissues $(25,26)$. Our Northern blot analysis correlates well with that reported for guinea pig eotaxin with the exception of lung 

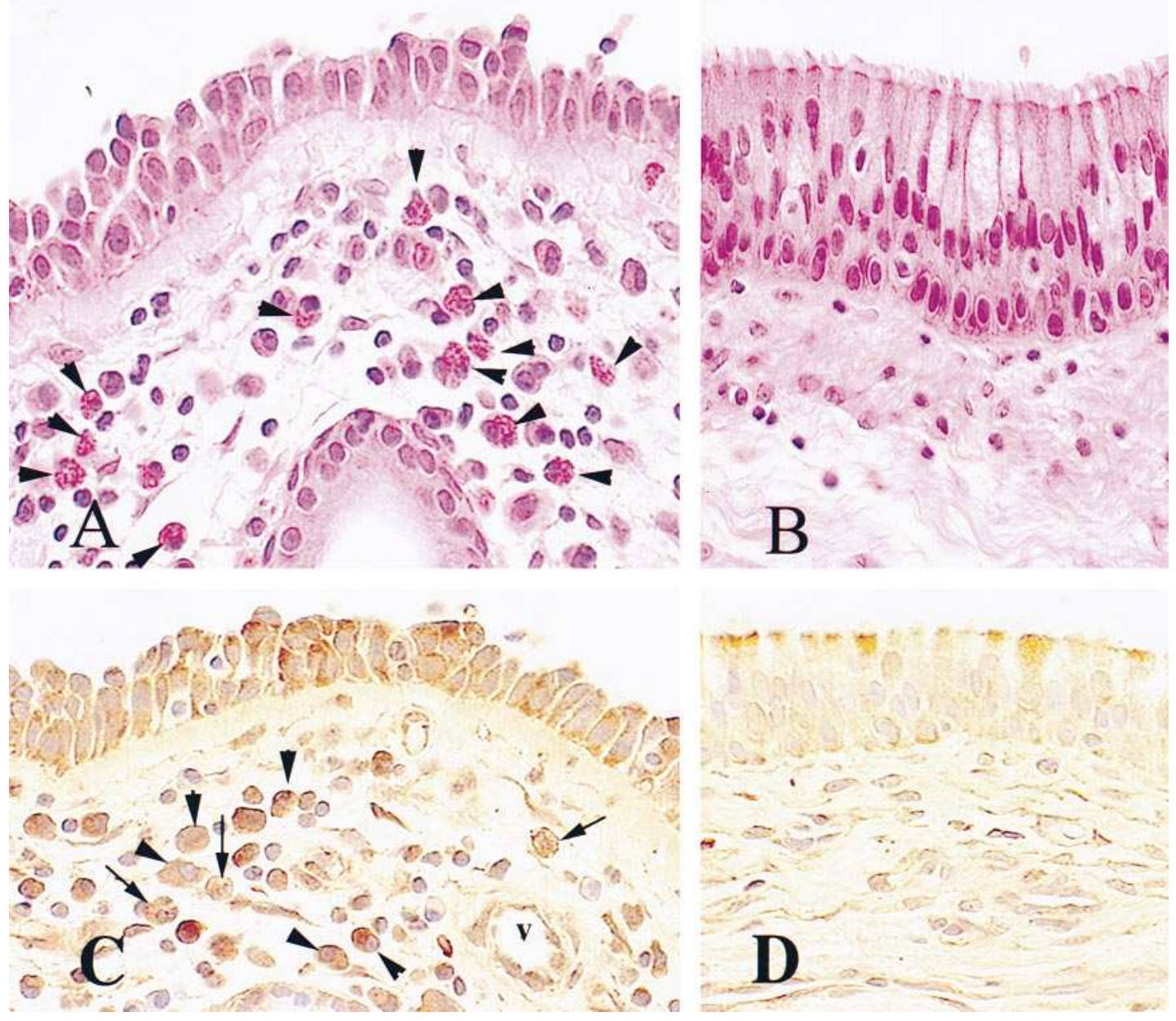

Figure 7. Photomicrographs of human nasal polyp ( $A$ and $C)$ and adjacent nasal mucosa $(B$ and $D)$. The polyp $(A)$ is characterized by extensive submucosal infiltration by eosinophils (arrowheads) and attenuation of the overlying respiratory epithelium. Immunoperoxidase staining of step sections of the polyp $(C)$ with antieotaxin mAb 6 99 revealed intense immunoreactivity to epithelium, endothelium lining venules $(v)$, eosinophils (arrows), mononuclear cells (arrowheads), and spindle cells. In contrast, the adjacent respiratory tissue is characterized by normal pseudostratified columnar epithelium and no eosinophil infiltration $(B)$, and immunostaining for eotaxin shows only light constitutive immunoreactivity to epithelium and submucosal mesenchymal cells $(D)$. ( $A$ and $B)$ Hematoxylin and eosin, $\times 1,450 ;(C$ and $D)$ ABC-peroxidase technique with Mayer's hematoxylin, $\times 1,450$.

where it appears to be expressed more abundantly in guinea pig. A striking similarity between guinea pig and human was the presence of eotaxin message in the heart, but not in skeletal muscle. The expression in heart may relate to the pathogenesis of endomyocardial fibrosis, a condition which is common in patients with hypereosinophilic syndrome (47). A comprehensive analysis of the expression of eotaxin by immunohistochemistry was beyond the scope of this study. However an analysis of inflamed nasal mucosal tissue revealed intense staining of respiratory epithelium, endothelial cells, leukocytes, and fibroblasts. These cell types are well characterized for their ability to produce other chemokines, such as MCP-1 and MIP-1 $\alpha$ (48-50). Of particular interest was the staining of eosinophils in mucosal tissue by antieotaxin mAbs. An autocrine production of eosinophilic chemotactic cytokines, yielding an amplification loop for eosinophil entry to mucosal tissue, has been proposed as a possible contributing factor in asthma and other allergies (14). We cannot exclude, however, the possibility that this staining resulted from receptor-bound material. The preliminary analysis of eotaxin expression in na- sal polyp showed a correlation between eosinophil recruitment and upregulated expression of eotaxin, although more tissues will need to be assessed before a definitive statement can be made. Staining for other eosinophilic chemokines did not reveal such a strong correlation (D.J. Ringler, unpublished observations), although the association between chemokine expression and the presence of inflammatory cells is still poorly understood and the conditions that give rise to eosinophil recruitment to a tissue are likely to be multifactorial.

The selective migration of eosinophils to eotaxin would suggest the existence of a receptor for eotaxin expressed only on eosinophils. The ligand binding experiments and $\left[\mathrm{Ca}^{2+}\right] \mathrm{i}$ analysis indicated that the dominant eosinophil eotaxin receptor also binds RANTES and MCP-3. These three ligands are the most potent chemokines for inducing eosinophil chemotaxis in vitro. Previous calcium desensitization studies $(21,22)$ implicated a RANTES/MCP-3 receptor on eosinophils that was distinct from CKR-1 (the MIP-1 $\alpha$ /RANTES receptor) identified by Neote et al. (27) and Gao et al. (28). Our [ $\left.\mathrm{Ca}^{2+}\right]$ i analysis showed that eotaxin could effectively desensitize eosin- 
ophils to subsequent $\left[\mathrm{Ca}^{2+}\right] \mathrm{i}$ responses to virtually all $\mathrm{CC}$ chemokines. This suggests that eotaxin is causing homologous desensitization of an eotaxin/MCP-3/RANTES receptor, and possibly cross-desensitization of other receptors. Cross-desensitization of chemoattractant receptors is well documented (51), and could result from a desensitization of the pathways leading to $\mathrm{Ca}^{2+}$ mobilization, downstream from receptor/ G-protein interactions (51). Alternatively, eotaxin may bind and signal through more than one receptor, although we have found that eotaxin does not bind to CKR-1 (unpublished observation). Our binding experiments support the existence of an "eotaxin/RANTES/MCP-3" receptor, although eotaxin appears to have a much stronger binding affinity for this receptor than RANTES or MCP-3. Nevertheless the in vitro chemotactic response of eosinophils to RANTES and MCP-3 was usually similar to that seen with eotaxin, suggesting that binding affinity does not correlate strictly with chemotactic activity. The number of binding sites for eotaxin on eosinophils $(4.8 \times$ $10^{4}$ receptors per cell) is much higher than the levels of expression of CKR-1 or CKR-2 on monocytes $(<3,000$ per cell) $(7$, $41,52)$ but is similar to the levels of IL-8 receptors on neutrophils $\left(\sim 6 \times 10^{4}\right.$ sites per cell) $(53)$. We have cloned a novel $\mathrm{CC}$ chemokine receptor from human eosinophils that mediates the binding and signaling of eotaxin, RANTES, and MCP-3 (Ponath, P., et al., manuscript submitted). This receptor is $72 \%$ identical to the CKR-1 and is very similar to an eosinophil restricted CC chemokine receptor reported recently by another group (54). The selective binding of eotaxin to a receptor on eosinophils, coupled with production of eotaxin by certain inflammatory cells and epithelium, provides a mechanism for the selective recruitment of eosinophils to inflamed mucosal tissue.

The relative contribution of eotaxin versus other chemoattractants in various eosinophil-related diseases will be an important topic for further investigation. Eotaxin will be a valuable tool for exploring the molecular mechanisms for eosinophil traffic, and possibly for the discovery of eosinophil CC chemokine receptor antagonists for blocking eosinophil recruitment in diseases such as asthma.

\section{Acknowledgments}

We thank Drs. Craig Gerard, Greg LaRosa, Dulce Soler, Eugene Butcher, and Tim Springer for assistance during the course of these experiments and for suggestions in the preparation of this manuscript. We also thank Michelle Rand and Michael Mansour for technical assistance, Dr. Prabhat Sehgal of the New England Regional Primate Center for assistance with the non-human primate experiments, and Dr. Richard Sibley (Stanford University School of Medicine, Stanford, CA) for supplying human nasal polyp.

Chemical synthesis work was supported by National Institutes of Health grant RO1 GM-50969-01.

\section{References}

1. Springer, T.A. 1994. Traffic signals for lymphocyte recirculation and leukocyte emigration: the multistep paradigm. Cell. 76:301-314.

2. Baggiolini, M., B. Dewald, and B. Moser. 1994. IL-8 and related chemotactic cytokines-CXC and CC chemokines. Adv. Immunol. 55:97-179.

3. Miller, M.D., and M.S. Krangel. 1992. Biology and biochemistry of the chemokines: a family of chemotactic and inflammatory cytokines. Crit. Rev. Immunol. 12:17-46.

4. Schall, T.J., and K.B. Bacon. 1994. Chemokines, leukocyte trafficking, and inflammation. Curr. Opin. Immunol. 6:865-873.

5. Oppenheim, J.J., C.O. Zachariae, N. Mukaida, and K. Matsushima. 1991. Properties of the novel proinflammatory supergene "intercrine" cytokine fam- ily. Annu. Rev. Immunol. 9:617-648.

6. Carr, M.W., S.J. Roth, E. Luther, S.S. Rose, and T.A. Springer. 1994 Monocyte chemoattractant protein 1 acts as a T-lymphocyte chemoattractant. Proc. Natl. Acad. Sci. USA. 91:3652-3656.

7. Ernst, C.A., Y.J. Zhang, P.R. Hancock, B.J. Rutledge, C.L. Corless, and B.J. Rollins. 1994. Biochemical and biologic characterization of murine monocyte chemoattractant protein-1. Identification of two functional domains. J. Immunol. 152:3541-3549.

8. Tanaka, Y., D.H. Adams, S. Hubscher, H. Hirano, U. Siebenlist, and S Shaw. 1993. T-cell adhesion induced by proteoglycan-immobilized cytokine MIP-1 beta. Nature (Lond.). 361:79-82.

9. Murphy, P.M. 1994. The molecular biology of leukocyte chemoattractant receptors. Annu. Rev. Immunol. 12:593-633.

10. Broaddus, V.C., A.M. Boylan, J.M. Hoeffel, K.J. Kim, M. Sadick, A Chuntharapai, and C.A. Hebert. 1994. Neutralization of IL-8 inhibits neutrophil influx in a rabbit model of endotoxin-induced pleurisy. J. Immunol. 152: 2960-2967.

11. Mulligan, M.S., M.L. Jones, M.A. Bolanowski, M.P. Baganoff, C.L. Deppeler, D.M. Meyers, U.S. Ryan, and P.A. Ward. 1993. Inhibition of lung inflammatory reactions in rats by an anti-human IL-8 antibody. J. Immunol. 150: $5585-5595$.

12. Sekido, N., N. Mukaida, A. Harada, I. Nakanishi, Y. Watanabe, and K. Matsushima. 1993. Prevention of lung reperfusion injury in rabbits by a monoclonal antibody against interleukin-8. Nature (Lond.). 365:654-657.

13. Cacalano, G., J. Lee, K. Kikly, A.M. Ryan, S. Pitts-Meek, B. Hultgren, W.I. Wood, and M.W. Moore. 1994. Neutrophil and B cell expansion in mice that lack the murine IL-8 receptor homolog. Science (Wash. DC). 265:682-684.

14. Weller, P.F. 1992. Roles of eosinophils in allergy. Curr. Opin. Immunol. 4:782-787.

15. Gleich, G.J., C.R. Adolphson, and K.M. Leiferman. 1993. The biology of the eosinophilic leukocyte. Annu. Rev. Med. 44:85-101.

16. Kay, A.B., and C.J. Corrigan. 1992. Asthma. Eosinophils and neutrophils. Br. Med. Bull. 48:51-64.

17. Wardlaw, A.J., R. Moqbel, O. Cromwell, and A.B. Kay. 1986. Plateletactivating factor. A potent chemotactic and chemokinetic factor for human eosinophils. J. Clin. Invest. 78:1701-1706.

18. Fernandez, H.N., P.M. Henson, A. Otani, and T.E. Hugli. 1978. Chemotactic response to human $\mathrm{C} 3 \mathrm{a}$ and $\mathrm{C} 5 \mathrm{a}$ anaphylotoxins. I. Evaluation of $\mathrm{C} 3 \mathrm{a}$ and C5a leukotaxis in vitro and under simulated in vivo conditions. J. Immunol. 120: 109-115.

19. Rand, T.H., W.W. Cruikshank, D.M. Center, and P.F. Weller. 1991. CD4-mediated stimulation of human eosinophils: lymphocyte chemoattractant factor and other CD4-binding ligands elicit eosinophil migration. J. Exp. Med. 173:1521-1528.

20. Rot, A., M. Krieger, T. Brunner, S.C. Bischoff, T.J. Schall, and C.A. Dahinden. 1992. RANTES and macrophage inflammatory protein 1 alpha induce the migration and activation of normal human eosinophil granulocytes. J. Exp. Med. 176:1489-1495.

21. Dahinden, C.A., T. Geiser, T. Brunner, V. von Tscharner, D. Caput, P. Ferrara, A. Minty, and M. Baggiolini. 1994. Monocyte chemotactic protein 3 is a most effective basophil- and eosinophil-activating chemokine. J. Exp. Med. 179:751-756.

22. Baggiolini, M., and C.A. Dahinden. 1994. CC chemokines in allergic inflammation. Immunol. Today. 15:127-133.

23. Kameyoshi, Y., A. Dorschner, A.I. Mallet, E. Christophers, and J.M. Schroder. 1992. Cytokine RANTES released by thrombin-stimulated platelets is a potent attractant for human eosinophils. J. Exp. Med. 176:587-592.

24. Jose, P.J., D.A. Griffiths-Johnson, P.D. Collins, D.T. Walsh, R. Moqbel, N.F. Totty, O. Truong, J.J. Hsuan, and T.J. Williams. 1994. Eotaxin: a potent eosinophil chemoattractant cytokine detected in a guinea pig model of allergic airways inflammation. J. Exp. Med. 179:881-887.

25. Jose, P.J., I.M. Adcock, D.A. Griffiths-Johnson, N. Berkman, T.N. Wells, T.J. Williams, and C.A. Power. 1994. Eotaxin: cloning of an eosinophil chemoattractant cytokine and increased mRNA expression in allergen-challenged guinea-pig lungs. Biochem. Biophys. Res. Commun. 205:788-794.

26. Rothenburg, M.E., A.D. Luster, C.M. Lilly, J.M. Drazen, and P. Leder. 1995. Constitutive and allergen-induced expression of eotaxin mRNA in the guinea pig lung. J. Exp. Med. 181:1211-1216.

27. Neote, K., D. DiGregorio, J.Y. Mak, R. Horuk, and T.J. Schall. 1993. Molecular cloning, functional expression, and signaling characteristics of a C-C chemokine receptor. Cell. 72:415-425.

28. Gao, J.L., D.B. Kuhns, H.L. Tiffany, D. McDermott, X. Li, U. Francke, and P.M. Murphy. 1993. Structure and functional expression of the human macrophage inflammatory protein 1 alpha/RANTES receptor. J. Exp. Med. 177: 1421-1427.

29. Charo, I.F., S.J. Myers, A. Herman, C. Franci, A.J. Connolly, and S.R. Coughlin. 1994. Molecular cloning and functional expression of two monocyte chemoattractant protein 1 receptors reveals alternative splicing of the carboxylterminal tails. Proc. Natl. Acad. Sci. USA. 91:2752-2756.

29a. Gonzalo, J.A., G.-O. Jia, V. Aguirre, A. Coyle, N. Jenkins, H. Katz, A. Lichtman, N. Copeland, M. Kopf, and J.C. Gutierrez-Ramos. 1996. The expression of mouse eotaxin parallels eosinophil accumulation during lung allergic in- 
flammatory reactions but is not restricted to a $\mathrm{TH} 2$ type response. Immunity. In press.

30. Sambrook, J., E.F. Fritsch, and T. Maniatis, editors. 1989. Molecular Cloning. A Laboratory Manual. 2nd ed. Cold Spring Harbor Laboratory Press, Cold Spring Harbor, NY.

31. Coligan, J.E., A.M. Kruisbeek, D.H. Margulies, E.M. Shevach, and W. Strober, editors. 1992. Current Protocols in Immunology. John Wiley and Sons, Inc., New York.

32. Hansel, T.T., J.D. Pound, D. Pilling, G.D. Kitas, M. Salmon, T.A. Gentle, S.S. Lee, and R.A. Thompson. 1989. Purification of human eosinophils by negative selection using immunomagnetic beads. J. Immunol. Methods. 122:97-103.

33. Clark-Lewis, I., B. Moser, A. Walz, M. Baggiolini, G.J. Scott, and R. Aebersold. 1991. Chemical synthesis, purification, and characterization of two inflammatory proteins, neutrophil activating peptide 1 (interleukin- 8 ) and neutrophil activating peptide. Biochemistry. 30:3128-3135.

34. Takahashi, K., Y. Sawasaki, J.-I. Hata, K. Mukai, and T. Goto. 1990. Spontaneous transformation and immortalization of human endothelial cells. In Vitro Cell \& Dev. Biol. 25:265-274.

35. Ringler, D.J., W.W. Hancock, N.W. King, N.L. Letvin, M.D. Daniel, R.C. Desrosiers, and G.F. Murphy. 1987. Immunophenotypic characterization of the cutaneous exanthem of SIV-infected rhesus monkeys. Apposition of degenerative Langerhans cells and cytotoxic lymphocytes during the development of acquired immunodeficiency syndrome. Am. J. Pathol. 126:199-207.

36. Ringler, D.J., W.W. Hancock, N.W. King, and G.F. Murphy. 1987. Characterization of nonhuman primate epidermal and dermal dendritic cells with monoclonal antibodies. A study of Langerhans cells and indeterminate cells in the rhesus monkey. Lab. Invest. 56:313-320.

37. Van Riper, G., S. Siciliano, P.A. Fischer, R. Meurer, M.S. Springer, and H. Rosen. 1993. Characterization and species distribution of high affinity GTPcoupled receptors for human rantes and monocyte chemoattractant protein 1. J. Exp. Med. 177:851-856.

38. Gong, J.H., and L.I. Clark. 1995. Antagonists of monocyte chemoattractant protein 1 identified by modification of functionally critical $\mathrm{NH}_{2}$-terminal residues. J. Exp. Med. 181:631-640.

39. Skelton, N.J., F. Aspiras, J. Ogez, and T.J. Schall. 1995. Proton NMR assignments and solution conformation of RANTES, a chemokine of the C-C type. Biochemistry. 34:5329-5342.

40. Smith, W.B., J.R. Gamble, I. Clark-Lewis, and M.A. Vadas. 1991. Interleukin-8 induces neutrophil transendothelial migration. Immunology. 72:65-72.

41. Meurer, R., G. Van Riper, W. Feeney, P. Cunningham, D. Hora, M.S. Springer, D.E. MacIntyre, and H. Rosen. 1993. Formation of eosinophilic and monocytic intradermal inflammatory sites in the dog by injection of human RANTES but not human monocyte chemoattractant protein 1, human macrophage inflammatory protein 1 alpha, or human interleukin 8. J. Exp. Med. 178:1913-1921.
42. Bischoff, S.C., M. Krieger, T. Brunner, A. Rot, V.V. Tscharner, M. Baggiolini, and C.A. Dahinden. 1993. RANTES and related chemokines activate human basophil granulocytes through different $\mathrm{G}$ protein-coupled receptors. Eur. J. Immunol. 23:761-767.

43. Bischoff, S.C., M. Krieger, T. Brunner, and C.A. Dahinden. 1992. Monocyte chemotactic protein 1 is a potent activator of human basophils. $J$. Exp. Med. 175:1271-1275.

44. Collins, P.D., S. Marleau, D.A. Griffiths-Johnson, P.J. Jose, and T.J. Williams. 1995. Cooperation between interleukin-5 and the chemokine eotaxin to induce eosinophil accumulation in vivo. J. Exp. Med. 182:1169-1174.

45. Schweizer, R.C., B.A. Welmers, J.A. Raaijmakers, P. Zanen, J.W. Lammers, and L. Koenderman. 1994. RANTES- and interleukin-8-induced responses in normal human eosinophils: effects of priming with interleukin-5. Blood. 83:3697-3704.

46. Gleich, G.J., C.R. Adolphson, and K.M. Leiferman, editors. 1992. Eosinophils. Inflammation: Basic Principles and Clinical Correlates. 2nd ed. J.I. Gallin, I.M. Goldstein and R. Snyderman, editors. Raven Press, Ltd., New York. $663-700$.

47. Weller, P.F., and G.J. Bubley. 1994. The idiopathic hypereosinophilic syndrome. Blood. 83:2759-2779.

48. Standiford, T.J., M.W. Rolfe, S.L. Kunkel, J.P. Lynch, M.D. Burdick, A.R. Gilbert, M.B. Orringer, R.I. Whyte, and R.M. Strieter. 1993. Macrophage inflammatory protein-1 alpha expression in interstitial lung disease. J. Immunol. 151:2852-2863.

49. Yu, X., and D.T. Graves. 1995. Fibroblasts, mononuclear phagocytes, and endothelial cells express monocyte chemoattractant protein-1 (MCP-1) in inflamed human gingiva. J. Periodontol. 66:80-88.

50. Sousa, A.R., S.J. Lane, J.A. Nakhosteen, T. Yoshimura, T.H. Lee, and R.N. Poston. 1994. Increased expression of the monocyte chemoattractant protein-1 in bronchial tissue from asthmatic subjects. Am. J. Respir. Cell Mol. Biol. 10:142-147.

51. Tomhave, E.D., R.M. Richardson, J.R. Didsbury, L. Menard, R. Snyderman, and H. Ali. 1994. Cross-desensitization of receptors for peptide chemoattractants. Characterization of a new form of leukocyte regulation. $J$. Immunol. 153:3267-3275.

52. Yoshimura, T., and E.J. Leonard. 1990. Identification of high affinity receptors for human monocyte chemoattractant protein-1 on human monocytes. J. Immunol. 145:292-299.

53. Moser, B., C. Schumacher, V. von Tscharner, I. Clark-Lewis, and M. Baggiolini. 1991. Neutrophil-activating peptide 2 and gro/melanoma growthstimulatory activity interact with neutrophil-activating peptide 1 /interleukin 8 receptors on human neutrophils. J. Biol. Chem. 266:10666-10671.

54. Combadiere, C., S.K. Ahuja, and P.M. Murphy. 1995. Cloning and functional expression of a human eosinophil CC chemokine receptor. J. Biol. Chem. 270:16491-16494. 